\title{
Towards consistency, rigour and compatibility of risk assessments for ecosystems and ecological communities
}

\author{
EMILY NICHOLSON, ${ }^{1 \star}$ TRACEY J. REGAN,${ }^{1}$ TONY D. AULD,${ }^{2}$ EMMA L. BURNS,${ }^{3,4}$ \\ LAURIE A. CHISHOLM, ${ }^{5}$ VALERIE ENGLISH, ${ }^{6}$ STEPHEN HARRIS, ${ }^{7,8}$ \\ PETER HARRISON,${ }^{9}$ RICHARD T. KINGSFORD,${ }^{10}$ MICHELLE R. LEISHMAN, ${ }^{11}$ \\ DANIEL J. METCALFE,,${ }^{4,12}$ PHIL PISANU,${ }^{13}$ CHRISTOPHER J. WATSON, ${ }^{14}$ \\ MATTHEW WHITE,${ }^{15}$ MATT D. WHITE,${ }^{16}$ RICHARD J. WILLIAMS,${ }^{4,17}$ \\ BRUCE WILSON ${ }^{18,19}$ AND DAVID A. KEITH ${ }^{2,4,10}$ \\ ${ }^{1}$ School of Botany, The University of Melbourne, Melbourne, Vic. 3010, Australia (Email: \\ emily.nicholson@unimelb.edu.au), ${ }^{2} \mathrm{NSW}$ Office of Environment and Heritage, ${ }^{10}$ Centre for Ecosystem \\ Science, School of Biological, Earth and Environmental Sciences, University of NSW, ${ }^{11}$ Department of \\ Biological Sciences, Macquarie University, ${ }^{14}$ School of Environment, University of Technology, Sydney, \\ ${ }^{5}$ Institute for Conservation Biology and Environmental Management, School of Earth and \\ Environmental Sciences, University of Wollongong, Wollongong, ${ }^{9}$ Marine Ecology Research Centre, \\ School of Environment, Science and Engineering, Southern Cross University, Lismore, New South \\ Wales, ${ }^{3}$ Fenner School of Environment and Society, The Australian National University, \\ ${ }^{15}$ Commonwealth Department of Environment, Canberra, ACT, ${ }^{4}$ Long Term Ecological Research \\ Network, Terrestrial Ecosystem Research Network, ${ }^{8}$ School of Biological Sciences, University of \\ Queensland, St Lucia, ${ }^{12}$ CSIRO Ecosystem Sciences, Brisbane, ${ }^{18}$ Queensland Herbarium, ${ }^{19}$ Eco Logical \\ Australia Pty Ltd, Brisbane, Queensland, ${ }^{6}$ Western Australian Department of Parks and Wildlife, \\ Kensington, Western Australia, ${ }^{7}$ Invasive Species Branch, Department of Primary Industries, Parks, \\ Water and Environment, Hobart, Tasmania, ${ }^{13}$ Department of Environment, Water and Natural \\ Resources, Adelaide, South Australia, ${ }^{16}$ Arthur Rylah Institute for Environmental Research, Victorian \\ Department of Environment and Primary Industries, Melbourne, Victoria, and ${ }^{17}$ CSIRO Ecosystem \\ Sciences, Darwin, Northern Territory, Australia
}

\begin{abstract}
Ecosystem-level conservation is increasingly important at global, national and local levels. Many jurisdictions have developed and apply their own protocols for assessing the threat status of ecosystems, often independently, leading to inconsistencies between and within countries which are problematic for crossjurisdictional environmental reporting. Australia is a good example of these historic legacies, with different risk assessment methods applied nationally and in most states. The newly developed criteria for the International Union for the Conservation of Nature (IUCN) Red List of Ecosystems (RLE) provide a framework to compare and contrast apparently divergent protocols. We critically reviewed the Australian protocols and compared them with the IUCN RLE, based on the following components of a risk assessment protocol: (i) categories of threat; (ii) assessment units; (iii) underlying concepts and definitions; (iv) assessment criteria; (v) uncertainty methods; and (vi) assessment outcomes. Despite some differences in specific objectives, criteria and their expression, the protocols were structurally similar, included broadly similar types of criteria, and produced assessment outcomes that were generally concordant. Alignment with the IUCN RLE would not require extensive changes to existing protocols, but would improve consistency, rigour and robustness in ecosystem risk assessment across jurisdictions. To achieve this, we recommend: (i) more quantitative assessments of functional change; (ii) separation of management and policy considerations from risk assessment; and (iii) cross-referencing of assessment units in different jurisdictions. We argue that the focus on processes and ecological function, rather than only patterns, is key to robust risk assessment.
\end{abstract}

Key words: conservation status, IUCN, Red List of Ecosystems, threatened ecological communities, threatened ecosystems.

${ }^{\star}$ Corresponding author.

Accepted for publication April 2014.

(C) 2014 The Authors

doi: $10.1111 / \mathrm{aec} .12148$

Austral Ecology (C) 2014 Ecological Society of Australia 


\section{INTRODUCTION}

Conservation efforts are increasingly focussed at the ecosystem level, in addition to individual threatened species (Rodríguez et al. 2011; Holdaway et al. 2012). The Convention on Biological Diversity (CBD), with its associated Aichi Targets, to which the vast majority countries have committed, is one of many international agreements that require reporting on the changing status of ecosystems (COP10 2010). Others include the Ramsar Convention on Wetlands of International Importance, World Heritage Sites listed under the UNESCO World Heritage Convention, and potentially the Intergovernmental Science Policy Platform on Biodiversity and Ecosystem Services (IPBES). These reporting frameworks require substantial synthesis of local data on risks to ecosystems.

Historically, many national and regional jurisdictions have adopted legislative and regulatory frameworks that require threatened ecosystems to be considered in approval processes for developments and in targeting investments for biodiversity conservation (e.g. Council of the European Communities 1992; Commonwealth of Australia 1999; Government of South Africa 2004). The methods for identifying threatened ecosystems have evolved independently across these jurisdictions and although these protocols share common elements, there are several conceptual uncertainties and methodological inconsistencies between them (Nicholson et al. 2009). To resolve these challenges and promote a global synthesis for global reporting on ecosystem status, the International Union for the Conservation of Nature (IUCN) developed new criteria to support a Red List of Ecosystems ('IUCN RLE', Rodríguez et al. 2011; Keith et al. 2013), analogous to criteria that support the IUCN Red List of Threatened Species (IUCN 2001).

In Australia, as in other parts of the world, responsibilities for managing and reporting on biodiversity are shared among multiple governance structures, from global to local jurisdictions. There is a need for consistency in assessment and listing processes between jurisdictions for effective communication, joint environmental decision-making, scaling up for reporting, and to reduce regulatory burden for cross-jurisdictional development projects. Inconsistencies arise partly for historical reasons, as different jurisdictions designed their listing processes over time, and partly because jurisdictional needs vary and a single generic assessment process may not be appropriate.

The development of Red List criteria for ecosystems and their global adoption by IUCN (Rodríguez et al. 2011) presents an opportunity for improved consistency at national and lower scales. Australia represents a good case study because it comprises state and territory jurisdictions within a federation, with responsibilities for environmental and land manage-

doi:10.1111/aec.12148 ment divided among different levels of government, analogous to other regions such as Europe and the United States. Risk assessment protocols for ecosystems or ecological communities were developed semiindependently throughout Australia at state, national and global scales, representing a hierarchy. For well over a decade, risk assessments have been linked to environmental planning laws, policies and regulations (Keith 2009; Nicholson et al. 2009). A recent enquiry into federal environment legislation recommended improved alignment among state and federal listing processes for species and ecological communities (Hawke 2009).

We critically reviewed protocols for listing ecosystems in Australia, and compared them with each other and the IUCN RLE protocols (Table 1). We developed a framework for this comparison focussing on threat categories, definitions of assessment units, criteria for risk assessment, and provisions for dealing with scale and uncertainty. We illustrated the comparisons and evaluated the listing consequences of differences between protocols with case studies. We finish by discussing the implications of these differences for environmental reporting, priority setting, policy and management, and by identifying opportunities for improved alignment of assessment processes across jurisdictions. Our approach and interpretation of results provide guidance for resolving similar challenges in other multi-jurisdictional parts of the world.

\section{RISK ASSESSMENT PROTOCOLS REVIEWED}

We reviewed eight protocols for ecosystem risk assessment (Table 1): the IUCN RLE at the global level, the Australian national-level Environment Protection and Biodiversity Conservation Act 1999 (EPBC Act, Commonwealth of Australia 1999) and six protocols used in states and territories in Australia. South Australia (SA) and the Northern Territory do not currently have any legislation or listing protocols for ecological communities, although the IUCN RLE criteria have recently been trialled for state-level assessment in SA (Bonifacio \& Pisanu 2012).

Listing protocols comprised a set of decision rules, where each ecosystem is assessed against multiple criteria and assigned to an ordinal risk category. An ecosystem is assigned the highest threat category across all criteria assessed, following the IUCN Red List protocols for both ecosystems and species. We characterized the criteria and sub-criteria used in the protocols using three broad groupings: decline in distribution, restricted distribution and decline in function. We compared the interpretation of each group of criteria,

(C) 2014 The Authors Austral Ecology (C) 2014 Ecological Society of Australia 
Table 1. Features of the ecosystem threat assessment protocols reviewed. Threat categories $(\mathrm{CR}=$ critically endangered, $\mathrm{EN}=$ endangered, $\mathrm{VU}=$ vulnerable, $\mathrm{LC}=$ least concern), with non-threatened categories in brackets; and criteria used for assessment: decline in distribution; restricted distribution; and decline in function. For each criterion, quantitative indicates that the criterion has quantitative thresholds, semi-quantitative indicates that the criterion combines some quantitative and some qualitative components, qualitative describes purely qualitative (i.e. descriptive) criteria (see Table 2 for more detail), while N/A indicates that the criterion is not used; * indicates conditionality on demonstrated ongoing threat for the criterion to be applied; note that Queensland considers decline in function only within the Regional Ecosystem framework, not under the Vegetation Management Act. IUCN the International Union for the Conservation of Nature; RLE, Red List of Ecosystems

\begin{tabular}{|c|c|c|c|c|c|c|}
\hline $\begin{array}{l}\text { Protocol jurisdiction, } \\
\text { abbreviation name } \\
\text { \& key references }\end{array}$ & Unit of assessment & Definition of endpoint & $\begin{array}{l}\text { Threat } \\
\text { categories }\end{array}$ & $\begin{array}{l}\text { Decline in } \\
\text { distribution }\end{array}$ & $\begin{array}{l}\text { Restricted } \\
\text { distribution }\end{array}$ & $\begin{array}{l}\text { Decline in } \\
\text { function }\end{array}$ \\
\hline $\begin{array}{l}\text { Global: IUCN RLE } \\
\text { IUCN Red list of } \\
\text { Ecosystems (Keith } \\
\text { et al. 2013) }\end{array}$ & $\begin{array}{l}\text { Ecosystem: Complexes of organisms and their } \\
\text { associated physical environment, within an } \\
\text { area (after Tansley 1935). They have four } \\
\text { essential elements: a biotic complex; an } \\
\text { abiotic environment or complex; the } \\
\text { interactions within and between them; and a } \\
\text { physical space in which these operate. }\end{array}$ & $\begin{array}{l}\text { Collapse: transition beyond a bounded } \\
\text { threshold in one or more variables that } \\
\text { define the identity of the ecosystem. } \\
\text { Collapse is thus a transformation of identity, } \\
\text { loss of defining features and replacement by } \\
\text { a novel ecosystem. It occurs when all } \\
\text { occurrences lose defining biotic or abiotic } \\
\text { features, and characteristic native biota are } \\
\text { no longer sustained. }\end{array}$ & $\begin{array}{l}\text { Collapsed, } \\
\text { CR, EN, } \\
\text { VU, (near } \\
\text { threatened, } \\
\text { LC, data } \\
\text { deficient, } \\
\text { not } \\
\text { evaluated) }\end{array}$ & Quantitative & Quantitative & Quantitative \\
\hline
\end{tabular}

Commonwealth of
$\begin{aligned} & \text { Ecological Community: the extent in nature } \\ & \text { Australia: EPBC }\end{aligned}$
$\begin{array}{ll}\text { in the Australian jurisdiction of an } \\ \text { act }\end{array}$
$\begin{array}{ll}\text { assemblage of native species that: (i) inhabits } \\ \text { Environmental }\end{array}$

Protection and Biodiversity Act 1999

(Commonwealth of Australia 1999, 2000 TSSC 2004, 2010b

2013b) a particular area in nature; and (ii) meets the additional criteria specified in the regulations (if any) made for the purposes of this definition.
Extinction: Extinction (or collapse) of an ecological community includes situations where remaining occurrences are so functionally degraded that they cannot be restored (e.g. to a benchmark state) Remnants can be threatened with 'functional' extinction through on-going modifications that, whilst they may not lead to total destruction of all elements of the to total destruction of all elements of
community, are disrupting ecological community, are disrupting ecological
processes that are critical to maintain and recover the community. Functional degradation may be indicated by loss of functional biotic components of the ecological community or a breakdown of abiotic processes (e.g. nutrient cycling), such that characteristic native biota are no longer sustained within the ecological community's sustained within the ecological community's
range of natural variability. That is, when range of natural variability. That is, when
re-establishment of biotic and abiotic processes, species composition and community structure is unlikely within the foreseeable future, even with positive human intervention.

Extinction: not formally defined.

CR, EN, VU Quantitative Quantitative` Qualitative

\begin{tabular}{|c|c|c|c|c|c|c|}
\hline $\begin{array}{l}\text { New South Wales } \\
\text { (NSW) } \\
\text { New South Wales } \\
\text { Threatened Species } \\
\text { Conservation Act } \\
1995 \text { (New South } \\
\text { Wales Government } \\
\text { 1995, 2010; NSW } \\
\text { Scientific Committee } \\
\text { 2012) }\end{array}$ & $\begin{array}{l}\text { Ecological community: an assemblage of } \\
\text { species occupying a particular area. This } \\
\text { definition closely follows modern scientific } \\
\text { texts and embodies three requirements: (i) } \\
\text { the constituents of a community must be } \\
\text { species; (ii) the species need to be brought } \\
\text { together into an assemblage; and (iii) the } \\
\text { assemblage of species must occupy a } \\
\text { particular area. }\end{array}$ & Extinction: not formally defined. & CR, EN, VU & Quantitative & Quantitative $^{\star}$ & Qualitative \\
\hline $\begin{array}{l}\text { Victoria (Vic) } \\
\text { Native Vegetation } \\
\text { Framework under } \\
\text { Planning and } \\
\text { Environment Act } \\
\text { (DNRE 2002) }\end{array}$ & $\begin{array}{l}\text { Ecological vegetation classes (EVC): a type } \\
\text { of native vegetation classification that is } \\
\text { described through a combination of its } \\
\text { floristic, life form and ecological } \\
\text { characteristics, and through an inferred } \\
\text { fidelity to particular environmental } \\
\text { attributes. Each EVC includes a collection } \\
\text { of floristic communities (i.e. a lower level in } \\
\text { the classification that is based solely on } \\
\text { groups of the same species) that occur } \\
\text { across a biogeographic range, and although } \\
\text { differing in species, have similar habitat and } \\
\text { ecological processes operating. }\end{array}$ & $\begin{array}{l}\text { Extinction: probably no longer present in the } \\
\text { bioregion. }\end{array}$ & $\begin{array}{l}\text { Presumed } \\
\text { extinct, } \\
\text { EN, VU, } \\
\text { depleted, } \\
\text { rare, (LC) }\end{array}$ & Quantitative & Quantitative & Quantitative \\
\hline $\begin{array}{l}\text { Western Australia } \\
\text { (WA) } \\
\text { Western Australian } \\
\text { List of Definitions, } \\
\text { Categories and } \\
\text { Criteria for } \\
\text { Threatened and } \\
\text { Priority Ecological } \\
\text { Communities (DEC } \\
\text { 2010) }\end{array}$ & $\begin{array}{l}\text { Ecological community: a naturally occurring } \\
\text { biological assemblage that occurs in a } \\
\text { particular type of habitat. }\end{array}$ & $\begin{array}{l}\text { Presumed totally destroyed: an ecological } \\
\text { community that has been adequately } \\
\text { searched for but for which no representative } \\
\text { occurrences have been located. The } \\
\text { community has been found to be totally } \\
\text { destroyed or so extensively modified } \\
\text { throughout its range that no occurrence of it } \\
\text { is likely to recover its species composition } \\
\text { and/or structure in the foreseeable future. }\end{array}$ & $\begin{array}{l}\text { Presumed } \\
\text { totally } \\
\text { destroyed, } \\
\text { CR, EN, } \\
\text { VU }\end{array}$ & Quantitative* & Quantitative` & Quantitative^ \\
\hline
\end{tabular}

Ecological community: an assemblage of species occupying a particular area. This definition closely follows modern scientific texts and embodies three requirements: (i) the constituents of a community must be species; (ii) the species need to be brought together into an assemblage; and (iii) the assemblage of species must occupy a particular area.

Ecological vegetation classes (EVC): a type of native vegetation classification that is described through a combination of its floristic, life form and ecological

characteristics, and through an inferred fidelity to particular environmental attributes. Each EVC includes a collection of floristic communities (i.e. a lower level in the classification that is based solely on groups of the same species) that occur across a biogeographic range, and although differing in species, have similar habitat and

Western Australia (WA)

Western Australian List of Definitions, Categories and Criteria for

Threatened and

Priority Ecological Communities (DEC 2010) ecological processes operating.

Ecological community: a naturally occurring $P$ biological assemblage that occurs in a particular type of habitat.

\footnotetext{
Presumed totally destroyed: an ecological community that has been adequately searched for but for which no representative occurrences have been located. The community has been found to be totally destroyed or so extensively modified throughout its range that no occurrence of it is likely to recover its species composition and/or structure in the foreseeable future.
}

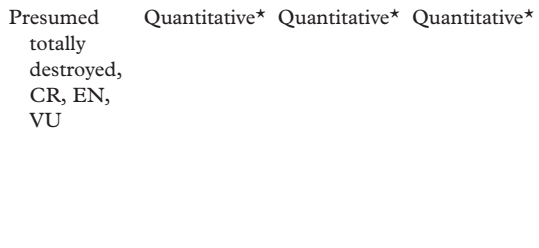
totally destroyed $\mathrm{CR}, \mathrm{EN}$ $\mathrm{VU}$

Quantitative Quantitative Quantitative extinct, depleted, rare, (LC) 
Table 1. Continued

\begin{tabular}{|c|c|c|c|c|c|c|}
\hline $\begin{array}{l}\text { Protocol jurisdiction, } \\
\text { abbreviation name } \\
\text { \& key references }\end{array}$ & Unit of assessment & Definition of endpoint & $\begin{array}{c}\text { Threat } \\
\text { categories }\end{array}$ & $\begin{array}{l}\text { Decline in } \\
\text { distribution }\end{array}$ & $\begin{array}{l}\text { Restricted } \\
\text { distribution }\end{array}$ & $\begin{array}{l}\text { Decline in } \\
\text { function }\end{array}$ \\
\hline $\begin{array}{l}\text { Tasmania (Tas) } \\
\text { Schedule 3A of the } \\
\text { Nature Conservation } \\
\text { Act } 2002 \\
\text { (Government of } \\
\text { Tasmania 2002; } \\
\text { Harris \& Kitchener } \\
\text { 2005; DPIWE 2007) }\end{array}$ & $\begin{array}{l}\text { Ecological vegetation community: the } \\
\text { entity used in the vegetation mapping } \\
\text { classification and characterized by floristic } \\
\text { and structural features that are more or less } \\
\text { consistent across its range. It may be } \\
\text { abbreviated to vegetation community or } \\
\text { community. Equivalent to TASVEG } \\
\text { mapping units. }\end{array}$ & No formal definition. & $\begin{array}{l}\text { EN, VU, } \\
\text { rare; } \\
\text { grouped } \\
\text { under a } \\
\text { single } \\
\text { formal } \\
\text { 'threatened' } \\
\text { category in } \\
\text { legislation. }\end{array}$ & Quantitative & Quantitative & N/A \\
\hline $\begin{array}{l}\text { Tasmania (Tas) } \\
\text { Schedule 3A of the } \\
\text { Nature Conservation } \\
\text { Act } 2002 \\
\text { (Government of } \\
\text { Tasmania 2002; } \\
\text { Harris \& Kitchener } \\
\text { 2005; DPIWE 2007) }\end{array}$ & $\begin{array}{l}\text { Ecological vegetation community: the } \\
\text { entity used in the vegetation mapping } \\
\text { classification and characterized by floristic } \\
\text { and structural features that are more or less } \\
\text { consistent across its range. It may be } \\
\text { abbreviated to vegetation community or } \\
\text { community. Equivalent to TASVEG } \\
\text { mapping units. }\end{array}$ & No formal definition. & $\begin{array}{l}\text { EN, VU, } \\
\text { rare; } \\
\text { grouped } \\
\text { under a } \\
\text { single } \\
\text { formal } \\
\text { 'threatened' } \\
\text { category in } \\
\text { legislation. }\end{array}$ & Quantitative & Quantitative & N/A \\
\hline $\begin{array}{l}\text { Queensland (Qld) } \\
\text { Queensland Vegetation } \\
\text { Management Act } \\
1999 \text { and Regional } \\
\text { Ecosystem framework } \\
\text { (Queensland } \\
\text { Government 1999; } \\
\text { Neldner et al. } 2012 \text {; } \\
\text { Queensland } \\
\text { Herbarium 2013) }\end{array}$ & $\begin{array}{l}\text { Regional ecosystem: a vegetation community } \\
\text { in a bioregion that is consistently associated } \\
\text { with a particular combination of geology, } \\
\text { landform and soil. Listings are based on a } \\
\text { list of ecosystems in the VMA } 1999 \\
\text { regulations and the Regional Ecosystem } \\
\text { Description Database (REDD) (Queensland } \\
\text { Herbarium 2013). }\end{array}$ & None. & $\begin{array}{l}\text { EN, 'of } \\
\text { concern', } \\
\text { (LC) }\end{array}$ & Quantitative & Quantitative & $\begin{array}{l}\text { Semi- } \\
\text { quantitative }\end{array}$ \\
\hline $\begin{array}{l}\text { Australian Capital } \\
\text { Territory (ACT) } \\
\text { Nature Conservation } \\
\text { Act } 1980 \text { (Flora and } \\
\text { Fauna Committee } \\
\text { 2008; ACT 2012) }\end{array}$ & $\begin{array}{l}\text { Ecological community: a group of } \\
\text { ecologically related species with shared } \\
\text { habitat characteristics that (i) may inhabit a } \\
\text { particular place; (ii) may vary in } \\
\text { composition within ecological limits; and } \\
\text { (iii) meet such additional criteria as may be } \\
\text { prescribed. }\end{array}$ & $\begin{array}{l}\text { Presumed extinct: a community that has } \\
\text { been destroyed totally since European } \\
\text { settlement or one that has been so } \\
\text { extensively modified that it is unlikely to } \\
\text { recover its species composition and structure } \\
\text { or re-establish its ecosystem processes in the } \\
\text { foreseeable future. }\end{array}$ & $\begin{array}{l}\text { EN } \\
\quad \text { (presumed } \\
\text { extinct, } \\
\text { ecological } \\
\text { communities } \\
\text { at lower } \\
\text { risk, rare, } \\
\text { insufficiently } \\
\text { known) }\end{array}$ & Quantitative & Quantitative ${ }^{\star}$ & Qualitative \\
\hline
\end{tabular}

variables used to assess ecosystems, and the quantitative thresholds used to allocate ecosystems to threat categories across the six assessment protocols (Table 1).

\section{Categories of threat}

The threat categories for most Australian protocols mirrored the IUCN categories of critically endangered $(\mathrm{CR})$, endangered (EN) and vulnerable (VU) (Table 1). The exceptions were Victoria, where the three categories were labelled EN, vulnerable and depleted, Queensland and Tasmania, which had only two threatened categories, and the Australian Capital Territory (ACT), with a single threatened category, EN (Table 1). In these four protocols, we interpreted the highest category, labelled 'endangered', as equivalent to CR in all other protocols based on their thresholds (see below). Hence, we interpreted the category labelled 'vulnerable' in Victoria and Tasmania and 'of concern' in Queensland as equivalent to EN in all other protocols, and 'depleted' in Victoria as equivalent to VU. This highlighted potential for linguistic confusion because categories labelled 'endangered' and 'vulner-

doi:10.1111/aec.12148 able' in Queensland, ACT, Victoria and Tasmania were not equivalent to those with the same labels in other protocols. Some protocols included categories such as Near Threatened or Rare, which were less threatened than VU (Table 1).

IUCN RLE, Victoria and Queensland included a 'Least Concern' non-threatened category (Table 1). Additional categories were defined for ecosystems with insufficient data for assessment ('Data Deficient' in IUCN RLE and 'Insufficiently Known' in ACT), and for ecosystems not yet assessed ('Not Evaluated' in IUCN). Under most protocols, unlisted ecosystems included those that have been assessed as not threatened, ecosystems for which assessment has been attempted but insufficient data existed, and those for which no assessment has been attempted.

\section{ASSESSMENT UNITS}

\section{Defining units of assessment}

All the protocols reviewed used a common scientific definition of their assessment units as assemblages of species within a particular area, environment or

(C) 2014 The Authors Austral Ecology (C) 2014 Ecological Society of Australia 
habitat (Table 1). There were semantic variations in terminology (e.g. ecosystem, ecological community or vegetation types). Some protocols focused on floristic communities (e.g. Victoria, Queensland, Tasmania), reflecting the terrestrial scope of policies or laws that they support. A few protocols referred explicitly to processes and interactions in the definition of assessment units (IUCN RLE and Victoria), implicit in other definitions. Given the similarity of definitions, we considered units of assessment as broadly equivalent and refer to them as ecosystems.

In common with other protocols, assessment units under the EPBC Act protocol are first defined on the basis of their characteristic assemblage of species, associated interactions and the physical environments occupied by the assemblage. Secondly, unlike other protocols, a customized set of condition classes is then defined in consultation with experts using thresholds for variables such as patch size, species richness, structural features, ratio of native to exotic cover, etc. The purpose of this second step is to exclude from parts of the regulatory process some occurrences of ecosystems that meet the description of the assemblage, interactions and environment, if their condition falls below threshold values that define poor condition (TSSC $2010 b$ ). At present, this step to provide guidance on appropriate actions for conservation after ecosystems are listed is not clearly separated from the risk assessment process (prerequisite to listing); condition classes are included within descriptions of the assessment units (e.g. TSSC 2013a) and embedded indirectly in some of the assessment criteria (see below).

\section{Classification of assessment units}

Although assessment units shared conceptually similar definitions across jurisdictions, their classification frameworks differed. Victoria, Tasmania and Queensland have prescriptive classifications of assessment units (described respectively in DNRE 2002; Harris \& Kitchener 2005; Queensland Herbarium 2013), permitting a comprehensive assessment throughout their jurisdictional domains. In contrast, listings in New South Wales (NSW), Western Australia (WA) and under the EPBC Act are not prescriptive. This reflects legislative requirements for public participation in the listing process, whereby the public may nominate an ecosystem for listing, as long as it conforms to the definition under the relevant legislation (e.g. in NSW, Preston \& Adam 2004). It also arose from a requirement to assess any biotic assemblage, not just those defined by vegetation types (e.g. English \& Blyth 1999). Although the lack of a classification framework makes a comprehensive and consistent assessment of the jurisdiction more difficult, it allows ecosystems to be assessed at a range of thematic scales and irrespec- tive of whether they are recognized within vegetation classification frameworks. For example, threatened assemblages of birds, lichens and fungi are listed in NSW (NSW Scientific Committee 1998, 2001), while thrombolite microbial assemblages and aquatic root mat invertebrate assemblages are listed nationally and in WA (e.g. ESSS 2000; TSSC 2010a). A flexible approach to assessment units also ensures unconstrained public participation in an important stage of environmental regulatory processes.

\section{Scale of assessment units}

Although assessment units were defined similarly across protocols, the thematic scale (i.e. level of classification) varied, depending on the context of the assessment (Nicholson et al. 2009). Larger jurisdictions may be expected to assess fewer, more broadly defined ecosystems than smaller ones. This reflects contrasting needs for risk assessments at global, regional, national and local scales. A global scale assessment of ecosystem status in the Americas, for example, aims to produce a broad overview of the status of biodiversity across two continents based on a classification of approximately 450 'macrogroups' (Rodríguez et al. 2012; Keith et al. 2013). At this thematic level, several hundred assessment units may be expected for a similar global-scale assessment across Australia. In contrast, local assessments are required to inform site-scale management and planning decisions (e.g. development approvals, restoration projects) that require a much finer resolution of risk assessment. Thus, at state level, in Victoria there are approximately 255 ecological vegetation classes (EVCs, DNRE 2002), and in Queensland over 1350 regional ecosystems (Queensland Herbarium 2013). If this thematic scale and diversity were implemented across the entire continent, a national classification in Australia may include over 4000 assessment units.

The number of assessable units over extensive domains may be limited by resourcing practicalities. Consequently, EPBC Act assessments and others such as NSW adopt a flexible approach (Keith 2009; Nicholson et al. 2009), listing fine scale units where appropriate (e.g. ESSS 2000) and amalgamating broad units where sub-units share similar biota, threats and status (e.g. TSSC 2006). Given the trade-offs for thematic scale, a hierarchical classification of ecosystem units would help to cross-reference broadly defined units, useful for global assessment with finer-scale units required for local applications. This would also help guide supervised remote sensing analyses to support detection of change. Although national classification systems exist in Australia (e.g. National Vegetation Information System (NVIS), ESCAVI 2003), they require further development before they can support an effective synthesis. 




Fig. 1. Decline thresholds used for decline in distribution across protocols; two thresholds apply under the International Union for the Conservation of Nature (IUCN) Red List of Ecosystems (RLE) (historic decline since 1750, and recent, current or future declines over 50 years), the EPBC Act (long-term decline, typically since European settlement or ca. 1750 [1826 in WA], and recent declines over 50 years) and NSW (dependant on whether threat has ceased); a third threshold is included for the EPBC Act (EPBC Act 1750 old), because communities assessed between 2000 and 2013 used more stringent long-term decline thresholds; *conditional on ongoing threat; ' $\wedge$ ' for Qld, Vic and Tas the endangered (EN) category is grouped with critically endangered (CR) thresholds in other protocols, 'of concern' and vulnerable (VU), respectively, are grouped with EN thresholds, 'depleted' in Vic is grouped with VU thresholds, while for Qld and Tas there is no category equivalent to VU and for WA VU is qualitatively defined.

\section{RISK ASSESSMENT}

\section{The endpoint of decline: collapse/extinction}

Risk assessment of ecosystems requires a defined endpoint of ecosystem decline analogous to species extinction (Nicholson et al. 2009; Keith et al. 2013). An explicitly defined endpoint of ecosystem decline is needed to interpret each of the assessment criteria to estimate how far a declining ecosystem has advanced towards collapse. Although most Australian protocols had a term for this endpoint (Table 1), its definition was lacking, incomplete or vague, with little grounding in ecological theory (Table 1). The EPBC Act had the most extensive discussion of the concept of extinction. The concept was more explicitly developed in the IUCN RLE, which also defined major sources of uncertainty (Keith et al. 2013).

doi:10.1111/aec. 12148

\section{Criteria for assessing decline in distribution}

All protocols included decline in distribution as a risk assessment criterion with quantitative thresholds, except the ACT (Table 1, Fig. 1). The interpretation and application of this criterion was similar across protocols. All protocols, except NSW, assessed declines in distribution since European settlement, consistent with the IUCN RLE historic timeframe (since 1750). NSW assessed declines over biologically relevant timeframes, appropriate to the life cycle and habitat characteristics of component species, typically three generation lengths or 10 years, whichever is the longer, similar to the IUCN species criteria (IUCN 2013). In most forests, woodlands and many shrub-dominated communities, three generations of the dominant species extended to European settlement (NSW Scientific Committee 2012), making timeframes for assessing decline similar

(C) 2014 The Authors Austral Ecology (C) 2014 Ecological Society of Australia 
across protocols. In addition, the EPBC Act assessed recent declines over shorter time scales of approximately 50 years, while the IUCN RLE assessed recent and projected future declines over the same time scale (50 years). In NSW and WA, the interpretation of thresholds for decline was conditional on continuing threats. Either more stringent thresholds (i.e. requiring greater levels of decline for similar threat categories) were applied (NSW) or the criterion was inapplicable (WA) if threats were understood and ceased.

The decline thresholds for allocating ecosystems to threat categories were generally similar (Fig. 1), and showed less variation than previous comparisons of global protocols (Nicholson et al. 2009). The thresholds for Queensland and Tasmania were more stringent than those of the IUCN RLE. EPBC Act thresholds were aligned with the IUCN RLE thresholds in 2013 (TSSC 2013b), although communities assessed between 2000 and 2013 used more stringent long-term decline thresholds only (TSSC 2010b), shown in Figure 1 as EPBC Act 1750 old, in addition to updated long-term and short-term thresholds, respectively EPBC Act 1750 and EPBC Act 50y. The reasons for different threshold values were unclear, except where they aligned with IUCN thresholds for species decline (e.g. NSW), although stringent thresholds may have been seen as a way of limiting the number of listings.

Estimates of decline in distribution will be sensitive to how the extant and past distributions are mapped, and how extant occurrences are delineated spatially from collapsed occurrences. This is an issue that clearly affects the entire assessment. With the exception of IUCN RLE, the lack of any requirement to specify thresholds of collapse could exacerbate inconsistencies in mapping of ecosystems across their range and/or at different times over which distributional change was assessed. The assessment of changes in distribution therefore needs an explicit definition of local collapse at a site or stand level as part of the description of the ecosystem under assessment. In Queensland, this is partly offset by application of mapping standards that define and map remnant woody vegetation consistently based on thresholds of relative cover, height and species composition of the canopy layer (Neldner et al. 2012).

\section{Criteria for assessing restricted distribution}

All of the protocols included a criterion assessing risks related to restricted distribution. All used quantitative area thresholds, except WA, which assessed distributions qualitatively (Table 1). This reflected widespread recognition that many processes that threaten the persistence of ecosystems are spatially explicit. For most protocols, listing under restricted distribution was

(C) 2014 The Authors

Austral Ecology (C) 2014 Ecological Society of Australia conditional on qualitative evidence of ongoing threat (Table 1 and Fig. 2). This distinguished between ecosystems that were naturally restricted but stable, and those at risk of collapse due to the impacts of threats on their restricted distribution. In Tasmania rarity thresholds alone were used as one of the criteria to determine eligibility for threatened status, irrespective of declines or threats. In Queensland and Victoria restricted distribution was used only as a conditional sub-criterion when assessing decline in distribution.

Four main metrics were used to measure restricted distribution. All protocols except WA included area of occupancy (AOO, range or simply area), the area occupied by the ecosystem (Fig. 2a). IUCN RLE, the EPBC Act, NSW and Victoria used extent of occurrence (EOO), a contiguous area enclosing all occurrences within a minimum convex polygon, including areas not occupied by the ecosystem (Fig. 2b). The number of locations was applied only in the IUCN RLE, based on a similar metric in the IUCN species criteria, where a location was defined as a 'geographically or ecologically distinct area in which a single threatening event can rapidly affect the ecosystem', and the size of the location depended on the area covered by the most serious plausible threat, rather than ecosystem patch size or distribution (Keith et al. 2013). Finally, the EPBC Act and Victoria used patch size as a metric of distribution, with ecosystems mostly in small patches considered threatened. We discuss this metric further in the next section in relation to fragmentation, one of the processes of functional decline.

The thresholds applied for measuring restricted distribution varied greatly between protocols (Fig. 2). The reasons for particular threshold values were undocumented, but may relate to attempts by protocol designers to control scale effects. AOO is highly sensitive to the scale (spatial and thematic) of mapping and measurement (Nicholson et al. 2009). To control scale-related artefacts, two protocols, IUCN RLE and NSW, explicitly specified a standard scale at which AOO should be measured for comparison with the thresholds. The NSW guidelines recommended $4 \mathrm{~km}^{2}$ grids (following species recommendations in IUCN 2013) while the IUCN RLE measured AOO using $100 \mathrm{~km}^{2}$ grid cells, with commensurately larger thresholds (Fig. 3). For Queensland, Victoria and Tasmania scaling was controlled implicitly because thresholds applied to specific classifications and associated maps with fixed scales across the jurisdictions.

\section{Scale and thresholds}

To investigate sensitivities of AOO to spatial scale, we extended the analysis by Nicholson et al. (2009). We calculated AOO for 181 ecological communities from NSW (Tozer et al. 2006), based on grids of varying 
(a) AOO

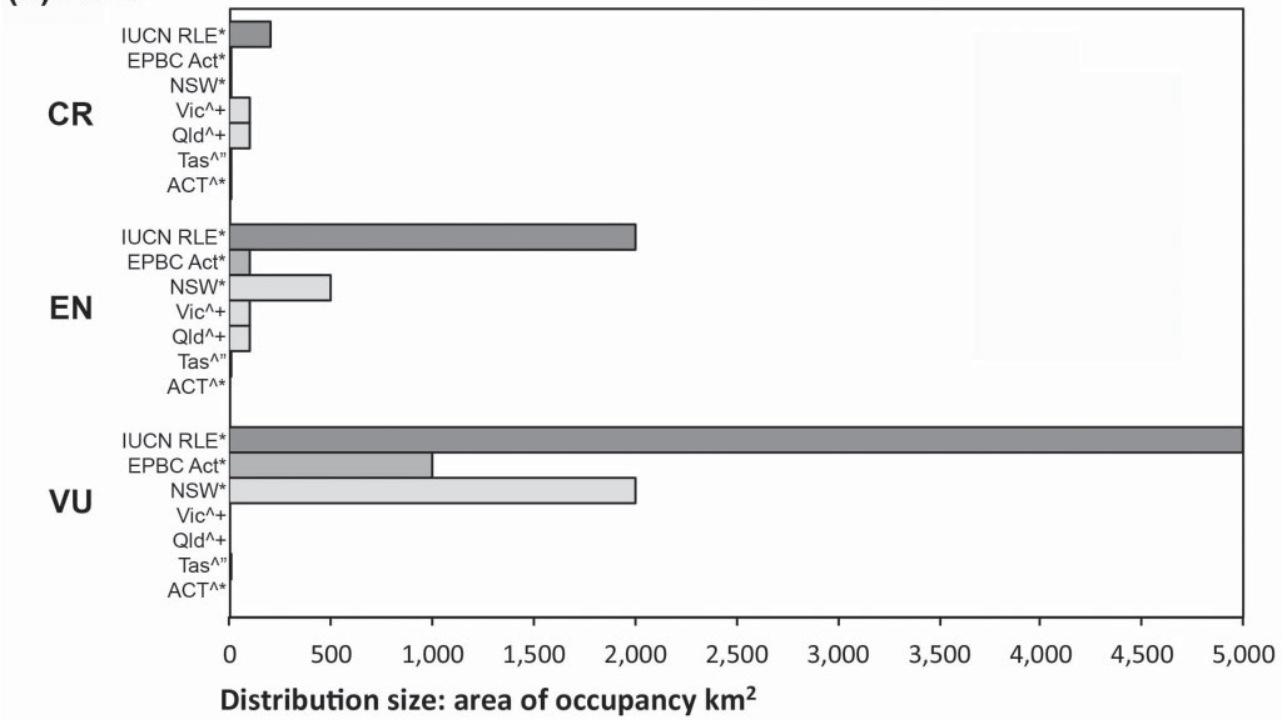

(b) EOO



Fig. 2. Restricted distribution thresholds for (a) area of occupancy (AOO) and (b) extent of occurrence (EOO); note that AOO under the International Union for the Conservation of Nature (IUCN) Red List of Ecosystems (RLE) is measured not in $\mathrm{km}^{2}$ but in the number of $10 \times 10 \mathrm{~km}$ grid cells in which the ecosystem occupies more than $1 \%$ of the area; ${ }^{\star}$ Conditional on ongoing threat; ' $\wedge$ ' for Qld, Vic and Tas the endangered (EN) category is grouped with critically endangered (CR) thresholds in other protocols, 'of concern' and vulnerable (VU), respectively, are grouped with EN thresholds, 'depleted' in Vic is grouped with VU thresholds, while for Qld and Tas there is no category equivalent to VU and ACT only has EN; ' + ' AOO threshold in Qld and Vic used as a sub-criterion in conjunction with other thresholds such as \% decline; Tas has a separate category, rare, based on area thresholds, which can be combined with decline threshold-based categories (EN and VU).

dimensions from $0.125 \times 0.125 \mathrm{~km}$ to $16 \times 16 \mathrm{~km}$, encompassing the recommended range of scales and ecosystem maps used by different protocols (e.g. Neldner et al. 2012; NSW Scientific Committee 2012; Keith et al. 2013). We then estimated $a$ and $b$ in the model $A O O=a \times(\text { grid })^{b}$, where $b$ describes how AOO scales with grid size.

AOO was highly sensitive to scale, with $b$ varying between 0.32 and 1.75 (median 0.74). IUCN RLE and NSW produced similar threat status for most ecosystems analysed because different thresholds for AOO were scaled using grids of a standard size: only $12 \%$ of ecosystems were assigned different threat categories by these two protocols. In all cases, the dif- ference was by one threat category (e.g. EN under one and VU under the other). Five representative ecosystems shown in Figure 3 had the same threat category under the two protocols with appropriate scaling, despite different scaling patterns. In contrast, the EPBC Act protocol had no recommended scale of measurement of AOO. Without scaling, estimates based on fine scale maps could produce a small estimate of AOO and a high category of risk; conversely estimates based on coarse scale maps could underestimate risk. Where distribution data are unavailable at the standard scale required for comparison against fixed thresholds, area estimates can be readily scaled using GIS software.

(C) 2014 The Authors Austral Ecology (C) 2014 Ecological Society of Australia 


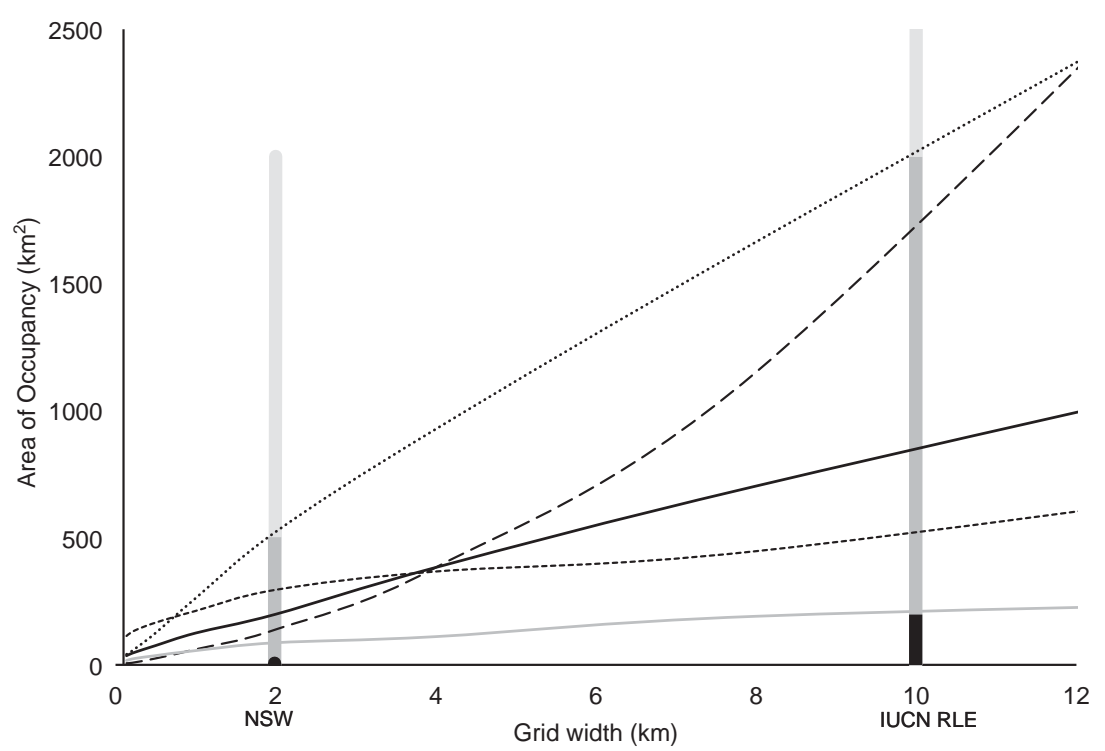

Fig. 3. The effects of scale of assessment (i.e. grid or pixel size) on the estimate of area of occupancy $\left(\mathrm{AOO}, \mathrm{km}^{2}\right)$, used to assess restricted distribution, for five threatened ecological communities in NSW (dashed and lighter lines); the community shown in the solid black line (p202, Burragorang Rocky slopes woodland) scales at the median rate with grid size (0.74, median of 181 ecosystems in NSW (Tozer et al. 2006); the other communities show a range of scaling factors, similar to the minimum, maximum, 25thand 75th percentiles for b-values observed; the vertical bars show the thresholds for critically endangered (CR) (black), endangered (EN) (mid-grey) and vulnerable (VU) (pale grey) for NSW and the International Union for the Conservation of Nature (IUCN) Red List of Ecosystems (RLE) at their recommended measurement scales (2 and $10 \mathrm{~km}$ grid widths, respectively); all five communities have the same threat status under NSW or IUCN RLE thresholds at the recommended grid size.

\section{Criteria for assessing decline in ecological function}

Almost all the protocols included criteria addressing functional decline, although most were qualitative (Tables 1,2). The EPBC Act, Queensland and Victoria include semi-quantitative criteria in which assessment of either the severity or the extent of degradation required quantitative evaluation, but not both (Table 2 ). Other protocols involved entirely qualitative assessment of ecosystem degradation, although NSW included a checklist of ecological processes for consideration.

Several protocols assessed the severity of functional decline by considering the likelihood of ecosystem recovery or restoration within a given timeframe, with or without intervention (Table 2). This requires assumptions and judgments about the likely or plausible range of management actions to be implemented and the resulting ecosystem responses. The use of recoverability, particularly with intervention, as an assessment criterion is problematic because it can confound risk assessment with management actions. This is because the likelihood of recoverability is dependent on management effort, resourcing and approaches, as well as available technology, which are not symptoms of risk. Even without intervention, inferences about recoverability may be conjectural unless the ecosystem

(C) 2014 The Authors

Austral Ecology (C) 2014 Ecological Society of Australia can be shown to recover when threats are removed in a controlled experimental manner.

Several ecological processes were identified across Australian protocols as relevant to assessing functional declines (Table 2). These include fragmentation, invasion of exotic species and declines in functionally important species. Although most protocols assessed these processes qualitatively, a few included quantitative criteria, for example to assess the severity of fragmentation using landscape geometry indices such as patch size (e.g. Fragstats, McGarigal et al. 2002), underpinned by empirical evidence that they can be useful proxies of fragmentation impacts on biodiversity, including reduced species movement or population viability as patches decline in size and become more isolated (Bender et al. 2003; Lindenmayer \& Fischer 2007). The EPBC Act and Victorian protocols used 'indicative' thresholds for patch size, below which any ecosystem may be considered threatened; similar criteria exist in other protocols internationally (Master et al. 2007; Rodriguez et al. 2007). Thresholds may be varied to take into account ecosystems with different spatial processes, however the methods for making such adjustments were undocumented.

The qualitative basis for assessment of functional decline or inclusion of quantitative criteria for dealing with only some of the possible mechanisms of functional decline created the greatest potential for 
Table 2. Protocols reviewed: ways of dealing with decline in function. Tasmania has no function-based criteria and is excluded; note that Queensland considers decline in function only within the Regional Ecosystem framework, not under the Vegetation Management Act. IUCN the International Union for the Conservation of Nature; RLE, Red List of Ecosystems

\begin{tabular}{|c|c|c|c|c|}
\hline Protocol & $\begin{array}{l}\text { Quantified } \\
\text { extent of } \\
\text { decline }\end{array}$ & $\begin{array}{l}\text { Quantified severity } \\
\text { of decline }\end{array}$ & Qualitative criteria & $\begin{array}{l}\text { Examples of measures of } \\
\text { decline in function } \\
\text { (abiotic and biotic variables) }\end{array}$ \\
\hline IUCN RLE & $\%$ area affected & $\begin{array}{l}\text { Abiotic (Environmental } \\
\text { degradation, Criterion C); } \\
\text { and biotic (disruption of } \\
\text { biotic processes \& } \\
\text { interactions, Criterion D). }\end{array}$ & & $\begin{array}{l}\text { Abiotic: desertification of rangelands, } \\
\text { eutrophication, de-humidification } \\
\text { of cloud forests, changed water } \\
\text { regime or hydroperiod, } \\
\text { salinization, structural } \\
\text { simplification, sea level rise, retreat } \\
\text { of ice masses } \\
\text { Biotic: species richness, species } \\
\text { composition and dominance, } \\
\text { functional diversity, trophic } \\
\text { diversity, spatial flux of organisms, } \\
\text { structural complexity. }\end{array}$ \\
\hline EPBC Act & & $\begin{array}{l}\text { Loss of decline of a } \\
\text { functionally important } \\
\text { species (Criterion } 3.1 \text {, } \\
\text { conditional on qualitative } \\
\text { criterion } 3.2 \text { ). } \\
\text { Rate of continuing decline in } \\
\text { a population of functionally } \\
\text { important species } \\
\text { (Criterion 5a). } \\
\text { Small geographic distribution } \\
\text { measured by patch size } \\
\text { (Criterion 2). }\end{array}$ & $\begin{array}{l}\text { Restoration of structure and } \\
\text { function unlikely within specified } \\
\text { timeframes (Criterion } 3.2 \text { ) } \\
\text { Reduction in integrity across most } \\
\text { of its geographic distribution } \\
\text { [. . . as indicated by } \\
\text { degradation of the community } \\
\text { or its habitat, or disruption of } \\
\text { important community processes } \\
\text { (Criteria } 4 \text { and } 5 \text { b). } \\
\text { Small distribution coupled with } \\
\text { demonstrable threat (Criterion } \\
\text { 2). }\end{array}$ & $\begin{array}{l}\text { Abiotic: desiccation of humid } \\
\text { communities, disruption of fire } \\
\text { regimes, altered hydrology, salinity, } \\
\text { increase in nutrients } \\
\text { Biotic: population decline in } \\
\text { functionally important species } \\
\text { changes, in the identity and } \\
\text { number of component species, the } \\
\text { relative and absolute abundances } \\
\text { of those species, irretrievable loss } \\
\text { of native species, invasion by } \\
\text { non-native species, loss of } \\
\text { recruitment. }\end{array}$ \\
\hline NSW & & & $\begin{array}{l}\text { Extent and severity of reduction in } \\
\text { biotic and abiotic ecological } \\
\text { function: } \\
\text { (i) Change in community } \\
\text { structure } \\
\text { (ii) Change in species } \\
\text { composition } \\
\text { (iii) Disruption of ecological } \\
\text { processes } \\
\text { (iv) Invasion and establishment } \\
\text { of exotic species } \\
\text { (v) Degradation of habitat } \\
\text { (vi) Fragmentation of habitat }\end{array}$ & $\begin{array}{l}\text { Abiotic: Reduced stream flow in a } \\
\text { riparian system, rubbish dumping, } \\
\text { physical disturbance, increased } \\
\text { nutrients, reduction in median size } \\
\text { of patches, construction of roads } \\
\text { and tracks. } \\
\text { Biotic: Reduction in cover of } \\
\text { structurally dominant species, } \\
\text { reduction in cover of obligate } \\
\text { seeders due to increased fire } \\
\text { frequency, increase in cover or } \\
\text { abundance of exotic species, } \\
\text { reduced recruitment of key } \\
\text { species. }\end{array}$ \\
\hline Vic & $\begin{array}{l}\% \text { area } \\
\text { affected } \\
\text { (in conjunction } \\
\text { with \% decline } \\
\text { in distribution) }\end{array}$ & & $\begin{array}{l}\text { Severity of change in floristic } \\
\text { and/or structural diversity. } \\
\text { Ability to recover naturally in time. } \\
\text { Estimate of degradation can be } \\
\text { based on modelled data. }\end{array}$ & $\begin{array}{l}\text { Abiotic: Change in fire regime, } \\
\text { hydrological processes. } \\
\text { Biotic: grazing/browsing, invasion of } \\
\text { weeds \& pest pathogens. }\end{array}$ \\
\hline WA & & & $\begin{array}{l}\text { Change in abiotic processes and } \\
\text { biotic components, recoverability } \\
\text { (with or without human } \\
\text { intervention). }\end{array}$ & $\begin{array}{l}\text { Abiotic: hydrology, salinity, nutrient } \\
\text { enrichment, pollution, } \\
\text { inappropriate fire regimes. } \\
\text { Biotic: species composition, } \\
\text { community structure, weed } \\
\text { invasion, disease. }\end{array}$ \\
\hline Qld & $\%$ area affected & & $\begin{array}{l}\text { Degradation of abiotic and biotic } \\
\text { components, recoverability. }\end{array}$ & $\begin{array}{l}\text { Abiotic: degradation of soil surface, } \\
\text { salinity, surface compaction, loss of } \\
\text { organic matter, or sheet erosion, } \\
\text { fragmentation, inappropriate fire } \\
\text { regimes. } \\
\text { Biotic: floristic/faunal diversity, } \\
\text { weedinvasion, grazing pressure. }\end{array}$ \\
\hline ACT & & & $\begin{array}{l}\text { Disruption to abiotic and biotic } \\
\text { community processes. }\end{array}$ & $\begin{array}{l}\text { Abiotic: fire, flooding, altered } \\
\text { hydrology, salinity, nutrient } \\
\text { change. } \\
\text { Biotic: pollination, seed dispersal, soil } \\
\text { disturbance by vertebrates which } \\
\text { affect plant germination. }\end{array}$ \\
\hline
\end{tabular}


divergence and inconsistency among the Australian protocols. The IUCN RLE, in contrast, has a framework for quantifying both the severity and extent of decline for a wide range of degradation processes (Keith et al. 2013). It therefore provides a useful means of harmonization by accommodating ecological processes relevant to ecosystem persistence including those incorporated into the other protocols. Key elements of the IUCN RLE approach are to: (i) identify the salient process(es) driving functional decline; (ii) identify proximal and sensitive variables that represent the process; (iii) define a threshold value of the variable that represents ecosystem collapse; and (iv) estimate any trend of the variable towards the threshold of collapse (relative severity of degradation) (Keith et al. 2013). The EPBC Act and the IUCN RLE also included a quantitative estimate of the risk of collapse as a criterion (Criterion 6 and E respectively), allowing for interactions among multiple threats to be evaluated explicitly through ecosystem simulation models.

The utility of the IUCN RLE approach can be illustrated with the example of assessing functional decline caused by fragmentation under Criterion D (disruption to biotic processes). First, two pre-requisites are to (i) establish that fragmentation is a key mechanism of functional decline in the ecosystem under assessment and (ii) understand how it disrupts ecological processes. Second, this understanding must be applied to select the most suitable variable for estimating the severity of fragmentation effects and to define a threshold of collapse. This approach contrasts with using the same generic measure with fixed thresholds across all ecosystems. Often, the most suitable, proximal and sensitive fragmentation variable may represent biological outcomes of fragmentation processes, such as species movement, abundance of invasive species or changes in species composition or abundance, rather than a measure of landscape geometry. If landscape geometry is used to assess functional decline, some metrics may be more reflective of biological responses than others. In Australian tropical lowland rainforest, for example, species richness of various taxa in fragments is inversely related to patch isolation, but unrelated to patch size (D. Metcalfe, unpubl. data, 2014).

Third, the fragmentation estimates must be standardized relative to an ecosystem-specific threshold of collapse (i.e. the level of fragmentation at which the ecosystem is no longer able to sustain its defining features), which can be estimated empirically at particular sites (Keith et al. 2013). The fragmentation thresholds delineating each threat category are then scaled mathematically to the collapse threshold. This allows the assessment to be scaled to accommodate the biology of the ecosystem. For example, wetland patches may be connected by a mobile and functional waterbird fauna, compared with grassland fragments in which the characteristic mammalian fauna is regionally extinct and no longer plays its crucial role in plant dispersal, top-down regulation of woody biomass and predator-prey dynamics. The two ecosystems have different risks of collapse, even though their configuration of patch sizes may be similar. Although patch size thresholds in Australian protocols are 'indicative' and may be adjusted case by case, the protocols offer no guidance on when the default thresholds apply or how they should be varied in magnitude or direction for any given assessment, increasing the risk of inconsistent interpretations

Finally, the IUCN RLE focuses on fragmentationrelated change rather than absolute values of indices for landscape pattern. For example for an assessment based on patch size, IUCN RLE evaluates how rapidly the estimated patch size is declining towards the collapse threshold (expressed as a size distribution, percentile or some other metric) over the specified assessment time scales, rather than whether patch size was smaller than an absolute threshold at the present time. These important characteristics of the IUCN RLE provide a useful framework for synthesis of processes that other protocols intend to address, and therefore offer an opportunity to produce more accurate and consistent ecosystem-specific risk assessments.

\section{UNCERTAINTY}

Uncertainty is pervasive in ecosystem risk assessment (Regan et al. 2003; Nicholson et al. 2009; Keith et al. 2013). Key sources of uncertainty include: (i) incomplete knowledge, such as lack of data, poor understanding of key processes and model uncertainty; (ii) uncertain delineation of ecosystems in maps and mapping error; (iii) natural variability; and (iv) linguistic uncertainty due to vagueness (Regan et al. 2002). Two key sources of uncertainty specific to ecosystem risk assessment lie in the definition of an ecosystem, and uncertainty about when an ecosystem may be considered collapsed (Nicholson et al. 2009; Keith et al. 2013). Only four of the protocols we reviewed acknowledged or dealt with these uncertainties (IUCN RLE, EPBC Act, NSW and ACT).

Two complementary methods for dealing with uncertainty were represented among the protocols. The first involved a designated category for data deficient ecosystems. This category is assigned if too few data exist to support an assessment of any of the criteria (i.e. threatened and non-threatened status are equally likely outcomes, given the available data). Only the IUCN RLE, the EPBC Act and ACT incorporated this feature. None of the other Australian protocols formally distinguished data deficient ecosystems from those not evaluated or from those evaluated but failing to qualify for threatened status. 
The second method estimates the magnitude of uncertainty in each assessment variable (e.g. with confidence bounds), and propagates this through the assessment to obtain a plausible range of threat categories for each ecosystem (Burgman et al. 1999; Akçakaya et al. 2000). This is especially useful for less certain variables, such as the historic declines in distribution and function. The IUCN RLE and NSW protocols incorporated methods and guidelines for such implementation, largely derived from methods used in assessments of Red Listed species (IUCN 2013). The EPBC Act guidelines also identified bounded best estimates as a means of representing uncertainty, but provided less detail on how these should be used in assessments (TSSC 2004).

\section{COMPARISON OF THE OUTCOMES OF PROTOCOLS}

To compare the assessment outcomes based on the different protocols, we compiled 13 case studies of ecosystems listed nationally under the EPBC Act and/or at a state level within Australia (Table 3). For those not assessed with the IUCN RLE (Keith et al. 2013, we applied the IUCN RLE criteria. We interpreted equivalence of categories as described above (see 'Categories of threat'; Figs 1, 2). There were only three discrepancies and four partial discrepancies (where plausible ranges of threat overlapped) between threat categories assigned by different protocols among the 41 assessments of 13 ecosystems, although different criteria were invoked across protocols. These discrepancies are likely historical artefacts of the listing process, where ecosystems were originally listed as EN under earlier Commonwealth and NSW listing regulations that did not include the CR category. Revised assessments under the updated EPBC and NSW protocols may yet produce a CR outcome, in agreement with IUCN RLE.

These results suggest that closer alignment of Australian protocols with the IUCN RLE criteria is unlikely to result in radical change to current listings. A high level of concordance may be expected, despite the differences in criteria described above, given that the overall symptoms of threat addressed by the criteria and the intent of the protocols were similar.

\section{DISCUSSION}

There were strong overarching similarities among Australian risk assessment protocols for ecosystems. Key similarities included: the definition of assessment units; the rule-set structure of the protocols; the categories of threat; and the main types and underlying

doi:10.1111/aec. 12148 intent of assessment criteria for assessing distributional decline, restricted size of distribution and functional decline. There were differences in how criteria were expressed, whether criteria on ecosystem function were quantitative or qualitative, the quantitative thresholds for decline and distribution size, and the scaling of measured spatial variables. Our systematic comparison based on each component of risk assessment (structure, categories, definitions and supporting concepts, criteria, thresholds and outcomes) also provides a useful framework for identifying opportunities for harmonizing approaches within other regions such as Europe and the Americas.

In general, the high level of concordance in assessment outcomes suggests that the differences among Australian protocols were subtle compared with the overarching similarities. However, the fact that the same status was triggered by different criteria across different protocols suggests a compensatory effect of errors. Testing of a broader sample of ecosystems may therefore reveal a more conspicuous effect of differences in listing criteria on assessment outcomes. Likely sources of any effect include divergence in qualitative assessments of functional declines and differences in distribution thresholds and scaling.

Although Hawke (2009) strongly recommended greater alignment of listing processes across Australian jurisdictions, little detail was provided on how this could be achieved. It is important to recognize that different jurisdictions have different responsibilities for environmental management, and therefore have different needs for risk assessment. For example, local regulatory responsibilities demand assessments of finer-scale assemblages than is required for global environmental reporting against Aichi targets. Rather than seek identical listings across all jurisdictions, the goals of harmonization should be to achieve consistency of approach and methods in risk assessment and to ensure transparent cross-reference between listed units defined at different thematic scales in different jurisdictions, for example through a hierarchical classification.

We suggest that significant progress could be achieved towards harmonization through greater congruence with the international standard established by the IUCN RLE (Keith et al. 2013). This provides a strong theoretical synthesis of all elements represented across the other protocols and overcomes some significant methodological limitations related to quantification of change in ecosystem function, definition of the endpoint of decline and spatial scaling of distribution data. The IUCN RLE criteria are supported by a lucid and detailed exposition of underlying theory, as well as guidelines and illustrative examples (Keith et al. 2013). In comparison, supporting documentation of the Australian protocols,

(C) 2014 The Authors

Austral Ecology (C) 2014 Ecological Society of Australia 
Table 3. Risk assessment outcomes for a representative sample of ecosystems assessed under global (IUCN RLE), national $(\mathrm{EPBC})$ and various state listing protocols: threat status $(\mathrm{CR}=$ critically endangered, $\mathrm{EN}=$ endangered, $\mathrm{VU}=$ vulnerable $)$; over-arching criterion/criteria under which the ecosystem is listed, with protocol specific criterion in parentheses; and major threats to the ecosystem (all links were accessed on 19 June 2014)

\begin{tabular}{|c|c|c|c|c|}
\hline Ecosystem & IUCN RLE status & EPBC Act status & State status & Major threats \\
\hline $\begin{array}{l}\text { Coolibah - Black Box } \\
\text { woodland }\end{array}$ & $\begin{array}{l}\text { EN: Decline in function } \\
\text { (abiotic environment, } \\
\text { C1) (Supplementary } \\
\text { material, Keith et al. } \\
\text { 2013). }\end{array}$ & $\begin{array}{l}\text { EN: Restricted } \\
\text { distribution (patch } \\
\text { size, 2c); reduction } \\
\text { in integrity (4) } \\
\text { (TSSC 2011). }\end{array}$ & $\begin{array}{l}\text { Q1d EN: EPBC unit included } 5 \\
\text { Regional ecosystems (11.3.3, } \\
\text { 11.3.15, 11.3.16, 11.3.28 and } \\
\text { 11.3.37) listed as Of Concern (cf. } \\
\text { EN), mainly due to decline in } \\
\text { distribution (since } 1750 \text { ), but also } \\
\text { decline in function (Queensland } \\
\text { Herbarium 2013). } \\
\text { NSW EN: Reduction in distribution; } \\
\text { decline in function }{ }^{1} \text {. }\end{array}$ & $\begin{array}{l}\text { Land clearing, } \\
\text { changed } \\
\text { hydrological } \\
\text { regime, } \\
\text { grazing, weed } \\
\text { invasion. }\end{array}$ \\
\hline Blue Gum High Forest & $\begin{array}{l}\text { CR: Decline in } \\
\text { distribution (since } \\
\text { 1750, A3); restricted } \\
\text { distribution (AOO, } \\
\text { B2). }\end{array}$ & $\begin{array}{l}\text { CR: Decline in } \\
\text { distribution (since } \\
\text { 1750, 1); } \\
\text { Restricted } \\
\text { distribution (AOO, } \\
\text { 2a; patch size, 2c); } \\
\text { decline in function } \\
\text { (4) (TSSC 2005). }\end{array}$ & $\begin{array}{l}\text { NSW CR: Decline in distribution; } \\
\text { Restricted distribution (AOO); } \\
\text { Decline in function }{ }^{2} \text {. }\end{array}$ & $\begin{array}{l}\text { Land clearing, } \\
\text { weed invasion. }\end{array}$ \\
\hline $\begin{array}{l}\text { Cumberland Plain } \\
\text { Woodland }\end{array}$ & $\begin{array}{l}\text { CR: Decline in } \\
\text { distribution (since } \\
\text { 1750, A3) (Tozer et al. } \\
\text { 2014). }\end{array}$ & $\begin{array}{l}\text { CR: Restricted } \\
\text { distribution (patch } \\
\text { size, 2c); decline in } \\
\text { function (4) } \\
\text { (TSSC 2008a). }\end{array}$ & $\begin{array}{l}\text { NSW CR: Decline in distribution; } \\
\text { Decline in function }{ }^{3} \text {. }\end{array}$ & $\begin{array}{l}\text { Land clearing, } \\
\text { weed invasion. }\end{array}$ \\
\hline $\begin{array}{l}\text { Coastal sandstone } \\
\text { upland swamps }{ }^{4}\end{array}$ & $\begin{array}{l}\text { EN (EN-CR): Decline } \\
\text { in function (abiotic } \\
\text { environment, C2). }\end{array}$ & $\begin{array}{l}\text { EN (Under } \\
\text { consideration for } \\
\text { listing): restricted } \\
\text { distribution (AOO } \\
\text { 2b, patch size 2c), } \\
\text { continuing } \\
\text { detrimental change } \\
(5)^{5} \text {. }\end{array}$ & $\begin{array}{l}\text { NSW EN: Projected decline in } \\
\text { distribution, restricted distribution, } \\
\text { projected decline in function }{ }^{6} \text {. }\end{array}$ & $\begin{array}{l}\text { Climate change } \\
\text { (moisture) } \\
\text { subsidence due } \\
\text { to longwall } \\
\text { mining, land } \\
\text { clearing. }\end{array}$ \\
\hline $\begin{array}{l}\text { Semi-evergreen vine } \\
\text { thicket (state } \\
\text { assessment) }\end{array}$ & $\begin{array}{l}\text { EN: Decline in } \\
\text { distribution (since } \\
\text { 1750, A3), restricted } \\
\text { distribution (AOO, } \\
\text { B2). }\end{array}$ & $\begin{array}{l}\text { EN: Restricted } \\
\quad \text { distribution }(2)^{7} \text {. }\end{array}$ & $\begin{array}{l}\text { NSW EN: Decline in distribution, } \\
\text { restricted distribution }\end{array}$ & $\begin{array}{l}\text { Land clearing, } \\
\text { grazing, } \\
\text { changed fire } \\
\text { regimes, weed } \\
\text { invasion. }\end{array}$ \\
\hline Acacia loderi shrubland & $\begin{array}{l}\text { EN: Decline in function } \\
\text { (biotic processes, D3). }\end{array}$ & & NSW EN: Decline in function ${ }^{9}$. & $\begin{array}{l}\text { Overgrazing, lack } \\
\text { of regeneration } \\
\text { of key species. }\end{array}$ \\
\hline $\begin{array}{l}\text { Gnarled Mossy Cloud } \\
\text { Forest, Lord Howe } \\
\text { Island }\end{array}$ & $\begin{array}{l}\text { CR: Restricted } \\
\text { distribution (EOO, B1; } \\
\text { AOO, B2) (Auld and } \\
\text { Leishman 2014) }\end{array}$ & & $\begin{array}{l}\text { NSW CR: Restricted distribution, } \\
\text { projected decline in function }{ }^{10} \text {. }\end{array}$ & $\begin{array}{l}\text { Anthropogenic } \\
\text { climate change, } \\
\text { predation by } \\
\text { rats of key } \\
\text { species. }\end{array}$ \\
\hline $\begin{array}{l}\text { Eastern Stirling Range } \\
\text { Montane Heath and } \\
\text { Thicket }\end{array}$ & $\begin{array}{l}\text { CR: restricted } \\
\text { distribution (EOO, B1; } \\
\text { AOO, B2) (Barrett } \\
\text { and Yates 2014). }\end{array}$ & $\begin{array}{l}\text { EN: Restricted } \\
\quad \text { distribution }(2)^{11} \text {. }\end{array}$ & $\begin{array}{l}\text { WA CR: Restricted distribution (EOO) } \\
\text { and threats (Barrett 2000). }\end{array}$ & Root rot disease. \\
\hline $\begin{array}{l}\text { Shrublands on } \\
\text { southern Swan } \\
\text { Coastal Plain } \\
\text { ironstones } \\
\text { (Busselton Ironstone } \\
\text { shrublands) }\end{array}$ & $\begin{array}{l}\text { CR: Decline in } \\
\text { distribution (past } 50 \\
\text { years, A1; since } 1750 \text {, } \\
\text { A3), Restricted } \\
\text { distribution (EOO, } \\
\text { B1) (English and } \\
\text { Keith 2014) }\end{array}$ & $\begin{array}{l}\text { EN: Restricted } \\
\quad \text { distribution }(2)^{12}\end{array}$ & $\begin{array}{l}\text { WA CR: Restricted distribution (EOO) } \\
\text { and ongoing threats (Meissner and } \\
\text { English 2005). }\end{array}$ & $\begin{array}{l}\text { Root rot disease, } \\
\text { hydrological } \\
\text { change, weed } \\
\text { invasion, } \\
\text { altered fire } \\
\text { regimes. }\end{array}$ \\
\hline $\begin{array}{l}\text { Broad leaf tea-tree } \\
\text { (Melaleuca } \\
\text { viridiflora) } \\
\text { woodlands in high } \\
\text { rainfall coastal north } \\
\text { Queensland }\end{array}$ & $\begin{array}{l}\text { EN: Decline in } \\
\text { distribution (since } \\
\text { 1750, A3). }\end{array}$ & $\begin{array}{l}\text { EN: Decline in } \\
\text { distribution (since } \\
\text { 1750, 1); decline in } \\
\text { function (4) } \\
\text { (TSSC 2012). }\end{array}$ & $\begin{array}{l}\text { Q1d CR-EN: EPBC unit includes } 3 \\
\text { Regional Ecosystems (7.3.8, 8.3.2 } \\
\text { and 8.5.2) listed as EN (cf. CR in } \\
\text { IUCN RLE and EPBC) and } 2 \text { (7.5.4 } \\
\text { and 8.5.6) listed as Of Concern (EN), } \\
\text { mainly due to decline in distribution } \\
\text { (since 1750), but also decline in } \\
\text { function and restricted distribution } \\
\text { (Queensland Herbarium 2013). }\end{array}$ & $\begin{array}{l}\text { Land clearing soil } \\
\text { degradation. }\end{array}$ \\
\hline
\end{tabular}


Table 3. Continued

\begin{tabular}{|c|c|c|c|c|}
\hline Ecosystem & IUCN RLE status & EPBC Act status & State status & Major threats \\
\hline $\begin{array}{l}\text { Box-Gum Grassy } \\
\text { Woodland and } \\
\text { Derived Grassland } \\
\text { Communities }\end{array}$ & $\begin{array}{l}\text { CR: Decline in } \\
\text { distribution (since } \\
\text { 1750, A3), Decline in } \\
\text { function (biotic } \\
\text { processes, D3). }\end{array}$ & $\begin{array}{l}\text { CR: Decline in } \\
\text { distribution (since } \\
\text { 1750, 1); decline in } \\
\text { function (4) } \\
\text { (TSSC 2006). }\end{array}$ & $\begin{array}{l}\text { Q1d CR-EN: EPBC unit includes most } \\
\text { or part of } 6 \text { Regional Ecosystems } \\
(13.3 .1,13.11 .8,13.12 .8,13.12 .9 \text {, } \\
\text { 11.3.23, 13.3.4) listed as EN (cf. CR } \\
\text { in IUCN RLE and EPBC) and } 3 \\
\text { regional ecosystems (12.8.16, } \\
\text { 13.11.3 and 13.11.4) listed as Of } \\
\text { Concern (EN), mainly due to decline } \\
\text { in distribution (since 1750), but also } \\
\text { decline in function and restricted } \\
\text { distribution, with a further } 3 \text { of Least } \\
\text { Concern (LC) (Queensland } \\
\text { Herbarium 2013). } \\
\text { NSW EN: Decline in distribution, } \\
\text { decline in function }{ }^{13} \text {. } \\
\text { Vic: Broader EPBC unit includes three } \\
\text { communities listed locally as EN (cf. } \\
\text { CR in IUCN RLE and EPBC) in } \\
\text { most bioregions (locally in some as } \\
\text { VU, cf. EN in IUCN RLE and } \\
\text { EPBC) }\end{array}$ & $\begin{array}{l}\text { Land clearing, } \\
\text { fragmentation, } \\
\text { overgrazing, } \\
\text { exotic species. }\end{array}$ \\
\hline $\begin{array}{l}\text { Weeping Myall } \\
\text { Woodlands }\end{array}$ & $\begin{array}{l}\text { EN: Decline in } \\
\text { distribution (since } \\
\text { 1750, A3). }\end{array}$ & $\begin{array}{l}\text { EN: Decline in } \\
\text { distribution (since } \\
\text { 1750, 1); decline in } \\
\text { function (4) } \\
\text { (TSSC 2008b). }\end{array}$ & $\begin{array}{l}\text { Qld EN: Minor component of two } \\
\text { more broadly defined Regional } \\
\text { Ecosystems (11.3.2 and 11.3.28) } \\
\text { listed as Of Concern (EN) due to } \\
\text { decline in distribution (since 1750) } \\
\text { (Queensland Herbarium 2013). } \\
\text { NSW EN: Decline in distribution, } \\
\text { decline in function }{ }^{15} \text {. }\end{array}$ & $\begin{array}{l}\text { Land clearing, } \\
\text { fragmentation, } \\
\text { shrub decline, } \\
\text { weed invasion. }\end{array}$ \\
\hline $\begin{array}{l}\text { Swamps of the } \\
\text { Fleurieu Peninsula }{ }^{16}\end{array}$ & $\begin{array}{l}\text { CR: restricted } \\
\text { distribution (EOO, B1; } \\
\text { AOO, B2). }\end{array}$ & $\begin{array}{l}\text { CR: Decline in } \\
\text { distribution (since } \\
1750,1) \text {; decline in } \\
\text { function (4). }\end{array}$ & $\begin{array}{l}\text { SA CR }{ }^{17} \text { : restricted distribution (B1, } \\
\text { B2) }\end{array}$ & $\begin{array}{l}\text { Land clearing, } \\
\text { fragmentation, } \\
\text { wetland } \\
\text { degradation. }\end{array}$ \\
\hline
\end{tabular}

${ }^{1}$ NSW: http://www.environment.nsw.gov.au/threatenedSpeciesApp/profile.aspx?id=10175

${ }^{2}$ NSW: http://www.environment.nsw.gov.au/threatenedSpeciesApp/profile.aspx?id=10094

${ }^{3} \mathrm{NSW}$ : http://www.environment.nsw.gov.au/threatenedSpeciesApp/profile.aspx?id=10191

${ }^{4}$ the threat status of the Coastal sandstone upland swamps and Acacia loderi shrubland is uncertain under the IUCN RLE, and therefore a plausible range of threat categories is shown

${ }^{5}$ EPBC Act: http://www.environment.gov.au/node/35085

${ }^{6} \mathrm{NSW}:$ http://www.environment.nsw.gov.au/threatenedSpeciesApp/profile.aspx?id=20261

${ }^{7}$ EPBC Act: http://www.environment.gov.au/node/14552

${ }^{8} \mathrm{NSW}$ : http://www.environment.nsw.gov.au/threatenedSpeciesApp/profile.aspx?id=10749

${ }^{9} \mathrm{NSW}$ : http://www.environment.nsw.gov.au/threatenedSpeciesApp/profile.aspx?id=10017

${ }^{10} \mathrm{NSW}$ : http://www.environment.nsw.gov.au/threatenedSpeciesApp/profile. aspx?id=20263

${ }^{11}$ EPBC Act: http://www.environment.gov.au/biodiversity/threatened/communities/east-stirling.html

${ }^{12} \mathrm{EPBC}$ Act: http://www.environment.gov.au/biodiversity/threatened/communities/swan-ironstone.html

${ }^{13} \mathrm{NSW}$ : http://www.environment.nsw.gov.au/threatenedSpeciesApp/profile. aspx?id=10837

${ }^{14}$ Vic: http://www.dse.vic.gov.au/conservation-and-environment/ecological-vegetation-class-evc-benchmarks-by-bioregion

${ }^{15} \mathrm{NSW}$ : http://www.environment.nsw.gov.au/threatenedSpeciesApp/profile. $a s p x ? \mathrm{id}=20030$

${ }^{16}$ EPBC Act: http://www.environment.gov.au/node/14521

${ }^{17}$ South Australia is currently trialling the IUCN RLE criteria for listing ecosystems.

like others implemented elsewhere around the world (Nicholson et al. 2009), generally failed to articulate a clear or comprehensive justification for many of their structural features and sometimes failed to guide interpretation.

At a policy level, harmonization of local jurisdictions with the IUCN RLE would position Australia and other countries to implement their international responsibilities under the CBD and to report on Aichi targets (COP10 2010) more efficiently and effectively than if encumbered with different listing processes. Such alignment with an

doi:10.1111/aec.12148 international protocol is not unprecedented: most Australia jurisdictions applycriteria for assessing species threat that are generally aligned with the IUCN Red List of Threatened Species (Nicholson et al. 2009; IUCN 2013). The similarity of risk assessment outcomes from different protocols suggested that greater consistency of listing procedures could be achieved without substantial changes in listing outcomes across Australian jurisdictions. We recommend how Australian jurisdictions could more closely align with the new international standard in Table 4.

(C) 2014 The Authors

Austral Ecology (C) 2014 Ecological Society of Australia 
Table 4. Recommendations for harmonization of listing protocols with IUCN RLE. CR, critically endangered; EN, endangered; IUCN the International Union for the Conservation of Nature; RLE, Red List of Ecosystems; VU, vulnerable.

1. Adopt the IUCN RLE framework for quantitative assessment of ecosystem degradation (functional decline) that includes:

(a) Identification of key degradation processes and metrics that represent them accurately and sensitively.

(b) Ecosystem-specific thresholds of ecosystem collapse.

(c) Standardization of functional decline relative to the ecosystem-specific threshold of collapse.

(d) Ability to model effects of interactions between multiple threats.

2. Avoid conflating risk assessment with prioritization for policy and management action by:

(a) Separating any use of condition classes and other devices used to guide conservation action from the definition of ecosystem types.

(b) Excluding listing criteria that address restorability or recoverability of ecosystem degradation.

3. Adopt a uniform classification of three threat categories (CR, EN and VU) across all protocols. This requires the following adjustments to align equivalent threat categories and label them with the same names:

(a) Re-label the EN category in Queensland, Victoria and Tasmania as CR.

(b) Re-label the VU category in Victoria and Tasmania, and the 'of concern' category in Queensland as EN.

(c) Re-label the 'depleted' category in Victoria as VU.

4. Align quantitative thresholds for assessing distribution decline, restricted distribution and functional decline with those that delineate the different categories of threat in IUCN RLE.

5. Avoid scaling artifacts by adopting a standard scale and measurement method for assessing ecosystem distributions, preferably in alignment with IUCN RLE.

6. Deal with uncertainty by:

(a) Identifying Data Deficient ecosystems separate from those that are assessed as Least Concern or not yet evaluated.

(b) Quantifying the precision of estimates and propagating confidence intervals through the assessment process to document the range of plausible risk assessment outcomes.

One of the most significant advances in the IUCN RLE protocol is its methodological framework for quantitatively and transparently assessing decline in ecological function for a wide range of degradation processes. The Australian protocols relied predominantly on qualitative approaches to assess functional declines (Table 2). This makes it very difficult to assess functional decline and degradation consistently across different ecosystems with different assessors. The IUCN RLE approach (Table 4) is more transparent, conceptually comprehensive, strikes a balance between consistency and flexibility, and strongly justifies assessments of declines in ecosystem function. Improved assessment of processes and ecological function, rather than only patterns, is key to robust risk assessment.

A second important recommendation for harmonization with the international standard is to avoid conflating risk assessment with management and policy actions and priorities. The separation of these processes has been persuasively argued to ensure accurate environmental reporting (Possingham et al. 2002; Mace et al. 2008; Rodríguez et al. 2011). NSW provides the best example of implementing this principal. Its listing criteria exclude management considerations and uniquely, as far as we are aware, a scientific committee has statutory responsibility for risk assessment, fully independent of environmental regulation and planning activity. The conflation of risk assessment with management and policy, which occurs to varying degrees in other jurisdictions, is unsurprising given that one of the principal applications of risk assessment is to guide the implementation of statutory responsibilities for environmental regulation by government agencies. Devices such as condition catego-

(C) 2014 The Authors

Austral Ecology (C) 2014 Ecological Society of Australia ries and recoverability criteria are a means of focussing regulatory and management priorities on the occurrences thought to be most likely to persist and respond to management (TSSC 2013b). This of course is sensible, but has an opportunity cost if the prioritization process is not separated from the listing process. In such cases, listings will reflect management issues to varying degrees and may obscure underlying changes in status of biodiversity, reducing the value of threatened ecosystem lists as environmental reporting tools. Improved transparency and accuracy in environmental reporting could be achieved by avoiding the use of condition classes in the definition of ecosystem types and by excluding listing criteria that address restorability or recoverability of ecosystem degradation (Table 4).

Another important recommendation is to align the equivalent threat categories across the protocols and label them with the same names. This will resolve linguistic confusion (Regan et al. 2002) and facilitate clear and accurate communication across jurisdictions.

Encouragingly, some progress has already been made towards alignment. The South Australian Government, which previously lacked a risk assessment process for ecosystems, has adopted the IUCN RLE as the basis for preparing a listing of threatened ecosystems within that state (Bonifacio \& Pisanu 2012). The EPBC Threatened Species Scientific Committee has amended its guidelines so that its thresholds for assessing decline in distribution are identical to those in the IUCN RLE. We believe this progress illustrates how scientists can interact productively with policy makers to achieve stronger, more effective evidencebased policy and management outcomes for biodiversity conservation. 


\section{ACKNOWLEDGEMENTS}

This work stemmed from a workshop funded by the Australian Centre for Ecological Analysis and Synthesis (ACEAS) and Australian Research Council Linkage Grant LP LP130100435 awarded to DAK, EN, TJR, RTK, TDA and PP. We thank R. Holdaway, E. Wright and S. Long for discussions and comments on the manuscript. EN was funded by a Centenary Research Fellowship from the Faculty of Science at The University of Melbourne.

\section{REFERENCES}

ACT (2012) Nature Conservation Act 1980. Australian Capital Territory, Canberra.

Akçakaya H. R., Ferson S., Burgman M. A., Keith D. A., Mace G. M. \& Todd C. R. (2000) Making consistent IUCN classifications under uncertainty. Conserv. Biol. 14, 1001-13.

Auld T. \& Leishman M. R. (2014) Ecosystem risk assessment for Gnarled Mossy Cloud Forest, Lord Howe Island, Australia. Austral Ecol. in press (this issue).

Barrett S. \& Yates C. (2014) An IUCN assessment of a montane ecosystem in Mediterranean climate Western Australia: the decline of the Eastern Stirling Range Montane Heath and Thicket. Austral Ecol. in press (this issue).

Bender D. J., Tischendorf L. \& Fahrig L. (2003) Using patch isolation metrics to predict animal movement in binary landscapes. Landsc. Ecol. 18, 17-39.

Bonifacio R. \& Pisanu P. (2012) The Threatened Ecological Communities (TECs) Project, Progress Report January to June 2012. Department of Environment and Natural Resources, South Australia, Adelaide.

Burgman M., Keith D. \& Walshe T. (1999) Uncertainty in comparative risk analysis for threatened Australian plant species. Risk Anal. 19, 585-98.

Commonwealth of Australia (1999) Environment Protection and Biodiversity Conservation Act, Act No. 91 (including amendments to 2013). Commonwealth of Australia.

Commonwealth of Australia (2000) Environment Protection and Biodiversity Conservation Regulation 7.02: Criteria for Listing Threatened Ecological Communities, Statutory Rules 2000 No. 181 (including amendments to 2013). Commonwealth of Australia.

Council of the European Communities (1992) Council directive 92/43/EEC of 21 May 1992 on the conservation of natural habitats and of wild fauna and flora. Official fournal of the European Communities, Series L 206, 7-50.

COP10 (2010) Conference of the Parties to the Convention on Biological Diversity. Decision X/2, Strategic Plan for Biodiversity 2011-2020. Convention On Biological Diversity.

DEC (2010) Definitions, Categories and Criteria for Threatened and Priority Ecological Communities. Department of Conservation and Environment, Perth, Western Australia.

DNRE (2002) Victoria's Native Vegetation Management: A Framework For Action. Victorian Government Department of Natural Resources and Environment, Melbourne, Australia.

DPIWE (2007) Threatened Native Vegetation Communities: Process for Listing/delisting Communities. Department of
Primary Industries, Parks, Water and Environment, Hobart, Tasmania.

English V. \& Blyth J. (1999) Development and application of procedures to identify and conserve threatened ecological communities in the South-west Botanical Province of WA Pac. Conserv. Biol. 5, 124-38.

English V. \& Keith D. A. (2014) Assessing risks to ecosystems within biodiversity hotspots: a case study from southwestern Australia. Austral Ecol. in press (this issue).

ESCAVI (2003) Executive Steering Committee for Australian Vegetation Information, Australian Vegetation Attribute Manual: National Vegetation Information System, Version 6.0. Department of the Environment \& Heritage, Canberra.

ESSS (2000) Commonwealth Listing Advice on Aquatic root mat communities 1, 2, 3 and 4 in caves of the Leeuwin Naturaliste Ridge: Advice to the Minister for the Environment and Heritagefrom the Endangered Species Scientific Subcommittee (ESSS) on a Proposal to Add an Ecological Community to Schedule 2 of the Endangered Species Protection Act 1992 (ESP Act). Minister for the Environment and Heritage, Commonwealth of Australia, Canberra.

Flora and Fauna Committee (2008) Nature Conservation (Criteria and Guidelines for Declaring Threatened Species and Communities) Determination, made under the Nature Conservation Act 1980. Australian Capital Territory.

Government of South Africa (2004) National Environmental Management: Biodiversity Act (Act 10 of 2004). Government Gazette Vol. 467 No. 26436, Cape Town.

Government of Tasmania (2002) Nature Conservation Act 2002. Hobart, Tasmania.

Harris S. \& Kitchener A. (2005) From Forest to Fjaeldmark. Descriptions of Tasmania's Vegetation. Department of Primary Industries, Parks, Water and Environment, Printing Authority of Tasmania. Hobart.

Hawke A. (2009) The Australian Environment Act - Report of the Independent Review of the Environment Protection and Biodiversity Conservation Act 1999. Commonwealth of Australia, Canberra.

Holdaway R. J., Wiser S. K. \& Williams P. A. (2012) Status assessment of New Zealand's naturally uncommon ecosystems. Conserv. Biol. 26, 619-62.

IUCN (2001) IUCN Red List Categories and Criteria: Version 3.1. IUCN Species Survival Commission, Gland, Switzerland.

IUCN (2013) Guidelines for Using the IUCN Red List Categories and Criteria: Version 10.0. Standards and Petitions Working Group for the IUCN Species Survival Commission, Biodiversity Assessments Sub-Committee, Gland, Switzerland.

Keith D. A. (2009) The interpretation, assessment and conservation of ecological communities. Ecol. Manage. Restor. 10, S3-15.

Keith D. A., Rodríguez J. P., Rodríguez-Clark K. M. et al. (2013) Scientific foundations for an IUCN Red List of Ecosystems. PLOS ONE 8, e62111.

Lindenmayer D. B. \& Fischer J. (2007) Tackling the habitat fragmentation panchreston. Trends Ecol. Evol. 22, 12732.

Mace G. M., Collar N. J., Gaston K. J. et al. (2008) Quantification of extinction risk: IUCN's system for classifying threatened species. Conserv. Biol. 22, 1424-42.

McGarigal K., Cushman S. A., Neel M. C. \& Ene E. (2002) FRAGSTATS: Spatial Pattern Analysis, Program for 
Categorical Maps. Computer software program produced by the authors at the University of Massachusetts, Amherst.

Master L. L., Faber-Langendoen D., Bittman R. et al. (2007) NatureServe Conservation Status Factors. NatureServe, Arlington.

Neldner V. J., Wilson B. A., Thompson E. J. \& Dillewaard H. A. (2012) Methodology for Survey and Mapping of Regional Ecosystems and Vegetation Communities in Queensland. Version 3.2. Updated August 2012. p. 124. Queensland Herbarium, Queensland Department of Science, Information Technology, Innovation and the Arts, Brisbane.

New South Wales Government (1995) Threatened Species Conservation Act, No 101. New South Wales, Australia.

New South Wales Government (2010) Threatened Species Conservation Regulation 2010 under the Threatened Species Conservation Act 1995. NSW, Australia.

Nicholson E., Keith D. A. \& Wilcove D. S. (2009) Assessing the threat status of ecological communities. Conserv. Biol. 23, 259-74.

NSW Scientific Committee (1998) The Shorebird Community Occurring on the Relict Tidal Delta Sands at Taren Point Endangered Ecological Community Determination - Final Scientific Committee Determination. DEC (NSW), Sydney.

NSW Scientific Committee (2001) Mount Canobolas Xanthoparmelia Lichen Community - Endangered Ecological Community Determination - Final. DEC (NSW), Sydney.

NSW Scientific Committee. (2012) Guidelines for Interpreting Listing Criteria for Species, Populations and Ecological Communities under the NSW Threatened Species Conservation Act, Version 1.3. January 2012. Office of Environment and Heritage, Sydney NSW.

Possingham H. P., Andelman S. J., Burgman M. A., Medellín R. A., Master L. L. \& Keith D. A. (2002) Limits to the use of threatened species lists. Trends Ecol. Evol. 17, 503-7.

Preston B. J. \& Adam P. (2004) Describing and listing threatened ecological communities under the Threatened Species Conservation Act 1995 (NSW): part 2 - the role of supplementary descriptors and the listing process. Environ. Plann. Law f. 21, 372-90.

Queensland Government (1999) Vegetation Management Act. Queensland Government, Brisbane, Australia.

Queensland Herbarium (2013) Regional Ecosystem Description Database (REDD). Version 6.1 (February 2013). [Cited 19 June 2014.] Available from URL: http://www.ehp.qld.gov. au/ecosystems/biodiversity/regional-ecosystems/

Regan H. M., Akçakaya H. R., Ferson S., Root K. V., Carroll S. \& Ginzburg L. R. (2003) Treatments of uncertainty and variability in ecological risk assessment of single-species populations. Human Ecol. Risk Assess. 9, 889-906.

Regan H. M., Colyvan M. \& Burgman M. A. (2002) A taxonomy and treatment of uncertainty for ecology and conservation biology. Ecol. Appl. 12, 618-28.

Rodríguez J. P., Rodríguez-Clark K. M., Baillie J. E. M. et al. (2011) Establishing IUCN Red List Criteria for threatened ecosystems. Conserv. Biol. 25, 21-9.
Rodríguez J. P., Rodríguez-Clark K. M., Keith D. A. et al. (2012) The IUCN Red List of Ecosystems. SAPIENS 5. [Cited 19 June 2014.] Available from URL: http://sapiens.revues.org/ 1286

Rodriguez J. P., Balch J. K. \& Rodriguez-Clark K. M. (2007) Assessing extinction risk in the absence of species-level data: quantitative criteria for terrestrial ecosystems. Biodivers. Cons. 16, 183-209.

Tansley A. G. (1935) The use and abuse of vegetational concepts and terms. Ecology 16, 284-307.

Tozer M. G., Leishman M. R. \& Auld T. D. (2014) Ecosystem risk assessment for Cumberland Plain Woodland, New South Wales, Australia. Austral Ecol. in press (this issue).

Tozer M. G., Turner K., Simpson C. et al. (2006) Native Vegetation of Southeast NSW: A Revised Classification and Map for the Coast and Eastern Tablelands. Version 1.0. NSW Department of Environment and Conservation, NSW Department of Natural Resources, Sydney.

TSSC (2004) Ecological Communities: A Way Forward. Threatened Species Scientific Committee, Commonwealth of Australia, Canberra, Australia.

TSSC (2006) Commonwealth Listing and Conservation Advice on White Box-Yellow Box-Blakely's Red Gum Grassy Woodland and Derived Native Grassland from the Threatened Species Scientific Committee (TSSC) under the Environment Protection and Biodiversity Conservation Act 1999 (EPBC Act). Minister for the Environment and Heritage, Commonwealth of Australia, Canberra.

TSSC (2010a) Commonwealth Listing Advice on Thrombolite (microbialite) Community of a Coastal Brackish Lake (Lake Clifton) from the Threatened Species Scientific Committee (TSSC) under the Environment Protection and Biodiversity Conservation Act 1999 (EPBC Act). Minister for the Environment and Heritage, Commonwealth of Australia, Canberra.

TSSC (2010b) Guidelines for Nominating and Assessing the Eligibility for Listing of Ecological Communities as Threatened according to the Environment Protection and Biodiversity Conservation Act 1999 (EPBC Act) and the EPBC Regulations 2000. Threatened Species Scientific Committee, Commonwealth of Australia, Canberra.

TSSC (2013a) Commonwealth Listing and Conservation Advice for Lowland Grassy Woodland in the South East Corner Bioregion from the Threatened Species Scientific Committee (TSSC) under the Environment Protection and Biodiversity Conservation Act 1999 (EPBC Act). Minister for the Environment and Heritage, Commonwealth of Australia, Canberra.

TSSC (2013b) Guidelines for Nominating and Assessing the Eligibility for Listing of Ecological Communities as Threatened according to the Environment Protection and Biodiversity Conservation Act 1999 (EPBC Act) and the EPBC Regulations 2000 (EPBC Regulations). Threatened Species Scientific Committee, Commonwealth of Australia, Canberra. 